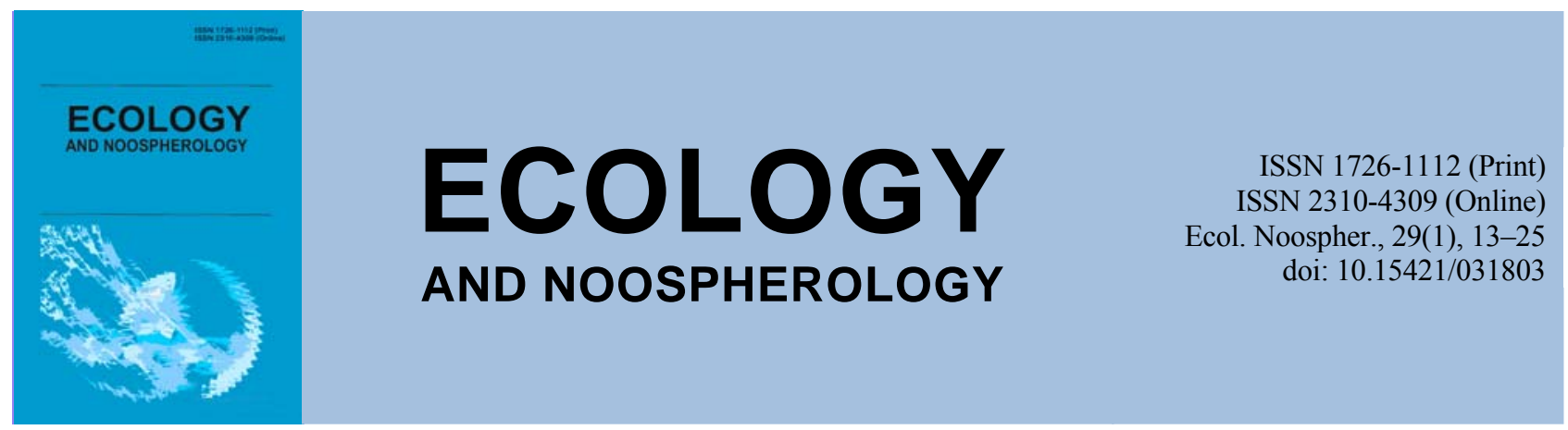

\title{
Prediction of the different genesis soils nitrogen systems status
}

\author{
V. L. Samokhvalova*, A. O. Khristenko*, L. O. Shedey*, \\ P. A. Samokhvalova**, O. V. Karatsuba* \\ *National Scientific Centre «O. N. Sokolovsky Institute for Soil Science \\ and Agrochemistry», Kharkiv, Ukraine \\ **V. N. Karazin Kharkov National University, Kharkov, Ukraine
}

Article info

Received 18.11.2017

Received in revised form 27.11.2017

Accepted 05.12.2017

National Scientific Centre «O. N. Sokolovsky Institute for Soil Science and

Agrochemistry»,

Chaikovska str., 4, Kharkiv,

61024, Ukraine.

Tel.: +38-067-687-90-63

E-mail:

v.samokhvalova.com@gmail.com

V. N. Karazin Kharkov National University,

Svobody square, 4, Kharkov, 61022, Ukraine.
Samokhvalova, V. L., Khristenko, A. O., Shedey, L. O., Samokhvalova, P. A., \& Karatsuba, O. V. (2018). Prediction of the different genesis soils nitrogen systems status. Ecology and Noospherology, 29(1), 13-25. doi:10.15421/031803

The method for predicting the levels of the easily hydrolysable nitrogen content in soils of various types of Polesie, Forest-steppe and Steppe climatic zones of Ukraine for the assessment of soil quality due to the background conditions, the influence of technological load (for the application of organo-mineral, organic and mineral fertilizer systems), and risk or influence of technogenic pollution by heavy metals (HM) is grounded. In the elaborated methodical approach is obtained a regression equation by the determination of new correlations of soil energy intensity indices (the calorific value of humus, soil energy reserves in a layer up to $20 \mathrm{~cm}$ ) in conjunction with the humus state and the use of mathematical and statistical analysis for determining the value of easily hydrolysable nitrogen with the ability to predict the quality of soils of various genesis, with the further extension of the method algorithm for different soil types, climatic zones due to technogenic HM pollution and technological load. The technical result of the elaborated method: by improving the determination of the levels of the easily hydrolysable nitrogen content in soils of different genesis for the evaluation of their quality by identifying the most correlated, diagnostically applicable integral basic indicators of soil properties, which allow the informativeness to make managerial decisions and to predict the quality of soils of different genesis in the content of easily hydrolysable nitrogen, as a biogenic element, due to the background conditions and anthropogenic loads with increased accuracy, speed and informativeness. Elaborated method can find application in the ecological standardization of the content of biogenic macroelements, the normalization of loads (technogenic, technological) on the soil system, agroecology for solving the problems of organic agriculture, bioenergy and energy of soil formation; diagnostics, evaluation, forecasting of the soils nitrogen systems state; the quality of humus and macroelement status of soils on indicators of ecological and energy status; effective ecological management of soils due to the background conditions, as well as for various anthropogenic influences and in scientific research for the investigating of biogeochemistry and biogenic macroelements of soil cover. Separate provisions of the elaborated method became an integral part of the proposals on adaptation to the Nitrate Council Directive 91/676 / EEC of 12.12.1991 on the protection of water from pollution caused by nitrates from agricultural sources, as amended by Regulation (EC) № 1882/2003 Cross Nitrogen Balances Handbook. Prospective directions of research in the field of diagnostics, assessment, forecasting of the state of soils nitrogen systems and the normalization of the elemental composition quality, in particular, the content of nutrient nitrogen are determined. In order to overcome the biogenic pollution (excessive accumulation of nitrogen compounds) in the environment (plants, waters), the normalization of nitrogen content in soils of different genesis should include: a) determination of the maximum permissible levels of mobile mineral forms of nitrate nitrogen by the elaboration of environmental requirements for nitrates contamination with plant products; b) normalization of the content of labile easily hydrolysable nitrogen and / or a dose of nitrogen fertilizers in conditions of sufficient and excessive moistening, considering the rapid processes of transformation of nitrogen compounds in soils; c) normalization of the soil nitrogen mineral compounds content in conditions of insufficient moistening and slowing down the processes of circulation of nitrogen compounds of soils. Distinctive features and advantages of the proposed elaboration in comparison with known methods and approaches are: 1) the express obtain of the accurate projected levels of easily hydrolysable nitrogen as a nutrient in the soil with the improving the accuracy of soil diagnosis by the use of the basic integrated indicators; 
2) providing opportunity for greater efficiency of forecasting data on the functioning of the nitrogen systems of different genesis soils, quality, environmental and energy state of soils due to the background conditions and anthropogenic loads while minimizing the cost of material resources; 3) empowerment of the user in determination of the easily hydrolysable nitrogen content in the soil without extensive chemical analysis by the choice of regression equations, based on the use of baseline soil properties of a particular type and subtype according to the available information; 4) versatility of the method by the suitability of detected dependencies of the proposed method for all soil types and subtypes, climatic zones and contaminants.

Keywords: soil; ecological condition of soils; macroelements; labile easily hydrolysable nitrogen; energy intensity; calorific value of humus; energy reserves in the layer up to $20 \mathrm{~cm}$; technogenic pollution; technological load; method; forecasting

\title{
Прогнозування стану азотних систем грунтів різного генезису
}

\author{
В. Л. Самохвалова*, А.О. Христенко*, Л. О. Шедєй*, \\ П. А. Самохвалова**, О. В. Карацюба*
}

*Національний науковий центр «Інститут грунтознавства та агрохімії

імені О. Н. Соколовського», Харків, Украӥна

**Харківський національний університет імені В. Н. Каразіна,

Харків, Україна

Обгрунтовано спосіб прогнозування рівнів умісту лабільного легкогідролізованого біогенного макроелементу азоту в грунтах різних типів природно-кліматичних зон Полісся, Лісостепу і Степу України для оцінювання якості грунтів за фонових умов, впливу технологічного навантаження (за застосування органо-мінеральної, органічної та мінеральної систем удобрення грунтів) та ризику і наявності техногенного забруднення важкими металами (ВМ). У розробленому методичному підході встановленням нових взаємозв'язків показників енергоємності грунтів (теплотворна здатність гумусу, запаси енергії грунту в шарі до $20 \mathrm{~cm}$ ) у спряженні з гумусовим станом та використанням математико-статистичного аналізу отримують регресійне рівняння визначення величини легкогідролізованого азоту з можливістю прогнозування якості грунтів різного генезису, з поширенням алгоритму способу на грунти різних типів певної природно-кліматичної зони за умов техногенного забруднення і технологічного навантаження. Технічний результат розробленого способу: за рахунок удосконалення визначення рівнів вмісту легкогідролізованого азоту у грунтах різного генезису для оцінювання їх якості шляхом визначення найбільш кореляційно пов'язаних, діагностично придатних інтегральних базових показників грунтових властивостей, які дозволять своєчасно, з підвищеною точністю, експресністю та інформативністю приймати управлінські рішення та прогнозувати якість грунтів різного генезису за вмістом легкогідролізованого азоту як біогенного елементу, за фонових умов та антропогенних навантажень. Спосіб може знайти застосування в екологічному нормуванні вмісту біогенних макроелементів, нормуванні навантажень (техногенних, технологічних) на грунтову систему, агроекології за вирішення питань органічного землеробства, біоенергетики і енергетики грунтоутворення; діагностики, оцінювання, прогнозування стану азотних систем грунтів; якості гумусу та макроелементного статусу грунтів за показниками екологоенергетичного стану; ефективного екологічного менеджменту грунтів як за фонових умов, так і за різних антропогенних впливів та в науково-дослідній практиці за дослідження біогеохімії та біогенних макроелементів грунтового покриву. Окремі положення розробленого способу стали складовою пропозицій з адаптації до Нітратної Директиви Ради ЄС 91/676/СЕС від 12.12.1991 р. про захист вод від забруднення, спричиненого нітратами з сільськогосподарських джерел, із змінами і доповненнями, внесеними Регламентом ЄC №1882/2003 Cross Nitrogen Balances Handbook. Визначено перспективні напрями з досліджень за тематикою діагностування, оцінювання, прогнозування стану азотних систем грунтів та нормування якості за елементним складом, зокрема вмістом біогенного азоту.

Ключові слова: грунт; екологічний стан; мікроелементи; лабільний легкогідролізований азот; енергоємність; теплотворна здатність гумусу; запаси енергії в шарі до 20 см; техногенне забруднення; технологічне навантаження; спосіб, прогнозування

\section{Вступ}

Відомо, що грунтовий покрив містить на один-півтора порядки більше азоту в порівнянні 3 біомасою суші (Kovda, 1985). Азот грунту представлений такими формами: 1) газоподібний азот у грунтовому повітрі та грунтовому розчині; 2) амоній, фіксований у глинистих мінералах; 3) азот органічних речовин; 4) мінеральний азот у грунтовому розчині та в обмінному стані; 5) азот рослинних решток (Orlov, 2005).

Молекули азоту є стійкими газовими сполуками, що перетворюються в аміак, окисли азоту, азотисту та азотну кислоти, солі за енергетичних витрат. Мінеральні сполуки азоту грунту, що вкрай необхідні для рослин, $\epsilon$ термодинамічно нестійкими. Амонійний азот здатний обмінно та необмінно сорбуватися грунтом, нітратний азот грунту - не сорбується грунтами, швидко мігрує до суміжних 3 грунтом середовищ, що призводить до втрат азоту внаслідок міграції у профілі грунту в процесах ерозії (з поверхневим стоком, через дефляцію) та вилуговування в нижні горизонти. 3 продуктами ерозії виноситься до 960 тис. т азоту, що значно більше, ніж вноситься 3 добривами. В Україні площа сільськогосподарських угідь, які зазнають згубного впливу вітрової ерозії, становить 6 млн. га, у роки з катастрофічними пиловими бурями 20 млн. га (проект Загальнодержавної програми використання та охорони земель). Також шляхами втрат азоту грунту $є$ денітрифікація та втрати в газоподібному стані внаслідок випаровування, споживання рослинами, закріплення кристалічною граткою мінералів і в плазмі мікроорганізмів грунту. Одночасно збільшуються екологічні ризики забруднення довкілля сполуками азоту внаслідок недосконалого управління балансом азоту та використання енергії в системі грунт - добриво - рослина вода (Smil, 1985; Schepers, Raun, 2008), біогенного (зокрема, евтрофікація та зміна біоценозів) та біотичного 
(витіснення аборигенних видів) забруднення довкілля (Mockler, Deakin, Archbold, 2016) за використання відходів промисловості, тваринництва, застосування їх стоків i рідкого гною в підвищених дозах як добрива; нераціонального застосування органічних і мінеральних добрив.

У сучасних умовах в агросфері країни спостерігається недотримання науково обгрунтованих систем удобрення та заходів 3 хімічної і водної меліорації грунтів, заміна традиційних систем землеробства інтенсивними спеціалізованими технологіями; обмеження площ, зайнятих травами; відсутність захисних зон навколо полів, що сприяе посиленню мінералізації органічної речовини грунту, трансформації сполук азоту, призводить до інтенсифікації процесів вимивання нітратів у підгрунтові води і посилення міграції азоту з поверхневим стоком. Окрім того, введення в сівозміни чистих парів також сприяє інтенсивному накопиченню нітратів у грунті, які можуть втрачатися при випаданні опадів.

В країнах $Є С$ застосовується від 150 кг/га діючої речовини азотних добрив (Франція) до 500 кг/га (Голландія). В Україні найбільша кількість внесеного у грунт азоту в 1986-1990 pp. становила 105 кг/га (65 кг/га 3 мінеральними туками і 40 кг/га - 3 органічними добривами); в сучасних умовах - близько 65 кг/га азоту. Однак виробництво і застосування азотних добрив у країні постійно зростає, що викликає необхідність уже зараз вживати термінові заходи щодо запобігання забруднення довкілля нітратами в майбутньому. До того ж живлення рослин незбалансоване (частка азотних добрив становить близько $65 \%$ ).

Різноманітність грунтово-кліматичних умов України (умови перезволоження Полісся 3 грунтами легкого гранулометричного складу, недостатнього i нестійкого зволоження Степу з грунтами важкого гранулометричного складу) впливає на кругообіг сполук азоту. Гідроморфні грунти Полісся та чорноземи Лісостепу і Степу України характеризуються високим природним умістом органічної речовини. Тому за іiі мінералізації роль природного грунтового азоту в забрудненні вод нітратами і в накопиченні його рослинами більш значна, ніж в країнах $€ С$.

Надходження азоту до грунтів проходить за рахунок несимбіотичної та симбіотичної фіксації (трансформація елементарного азоту в органічні сполуки); надходження 3 опадами; внесення добрив. Процеси біологічної фіксації та міграції визначають рівні надходження азоту в біосферу (Mishustin, 1979). Проте землеробство та промисловість хімічних туків значно змінили природний біогеохімічний цикл азоту, спрямувавши його не до атмосфери, а до грунту (Kovda, 1985).

Формами органічних сполук азоту грунту є гумусові кислоти (у складі гумінових кислот до 15-20\% від вмісту загального азоту; у складі фульвокислот - до 6-14\%), амінокислоти, білки, ферменти тощо (Yurko, 1979). Органічні сполуки азоту грунту розділяють на легко-, важкота негідролізовані фракції. Безпосереднім резервом доступного для рослин азоту $\epsilon$ лабільний легкогідролізований азот, уміст якого в чорноземних грунтах України складає до 10 \% від вмісту загального азоту та 3 глибиною вміст лабільного легкогідролізованого азоту в грунтах зменшується (Nosko, 2013).

Для характеристики азотного режиму грунтів важливо враховувати різну рухомість азотовмісних сполук у грунтах України. Внаслідок різниці в інтенсивності процесів мінералізації, гумусоутворення, величин запасів і типів гумусу грунтів найбільш рухомі азотовмісні сполуки у грунтах Полісся (крім торф'яних грунтів), менш рухомі - в грунтах Степу та найменш рухомі - у грунтах Лісостепу (Nosko, 2013).

Внаслідок важливої ролі азоту у процесах новоутворення гумусових речовин грунту, що тісно пов'язані з трансформацією речовин та енергії (Orlov, 1990), доцільно використовувати структурні взаємозв'язки показників азотного, гумусового та енергетичного стану для прогнозування екологічного стану грунтів за елементним (макро- та мікроелементим) статусом (Samokhvalova, Skrylnyk et al., 2016; Pat. na vynakhid 115014 UA, 2017; Pat. na korysnu model 120082 UA, 2017).

Для вирішення практичних задач із оптимізації екологічного стану грунтів, проведення їх комплексної оцінки та визначення напрямів еволюції доведено перспективність енергетичного підходу, що включає енергетичне оцінювання родючості грунтів за оцінювання властивостей, процесів та режимів. Базовими складовими енергетичного оцінювання грунтів $\epsilon$ оцінювання мінеральної частини грунтів, мінералогічного їх складу, гумусового стану та мікробіологічної активності, грунтовопоглинального комплексу, водно-фізичних властивостей, теплових властивостей та впливу на генезис і родючість грунтів геофізичних полів Землі (Savich et al, 2007). Таким чином, енергетичне оцінювання грунтів різного генезису потребує комплексного урахування всіх «носіїв» енергії. Однак методичні труднощі визначення енергетичних характеристик грунту значно обмежують їх використання як інструментів оцінювання та прогнозування екологічного стану грунтів за екологічними та продукційними функціями.

Відсутність точного прогнозування екологічного стану грунтів на рівні типу і підтипу актуалізує необхідність подальшого пошуку та залучення нових додаткових інтегральних показників грунтових властивостей та, насамперед, енергетичних показників і продуктивної функції (родючості) грунтів, зокрема для прогнозування стану азотних систем грунтів різного генезису за встановлення рівнів вмісту різних форм біогенного макроелементу. Отже, необхідним $є$ проведення додаткових поглиблених інформаційноаналітичних досліджень особливостей біогеохімії грунтового покриву певних регіонів та систематизація даних для визначення діагностичних критеріїв оцінювання якості грунту за вмістом азоту. До того ж на сьогодні не існує універсального методу визначення фракційного складу азоту для всіх типів грунтів за використання єдиного екстрагенту, що значно ускладнює узагальнення даних щодо статусу біогенного елементу азоту в грунтах та знижує їх точність.

Мета дослідження - розробити спосіб прогнозування стану азотних систем грунтів різного генезису для оцінювання їх якості за рахунок встановлення нових закономірних зв'язків інтегральних базових показників енергетичного у спряженні з гумусовим станом та азотного статусу грунтів, визначення найбільш кореляційно пов'язаних, діагностично придатних з них, що підвищують інформативність, точність і експресність прогнозування якості грунтів за вмістом азоту, як біогенного елементу, за фонових умов та антропогенних навантажень 3 виявленням відмінностей екологічного стану грунтів для прогнозу і нормування їх якості.

Розробку способу спрямовано на таке: 1) експресність отримання точних прогнозованих рівнів вмісту, зокрема, легкогідролізованого азоту як біогенного елементу у грунті 3 підвищенням точності грунтової діагностики за рахунок використання базових інтегральних показників; 2) забезпечення можливості отримання більшої результативності прогнозованих даних щодо функціонування азотних систем грунтів різного генезису, якості та еколого-енергетичного стану грунтів, за фонових умов та антропогенних навантажень 3 одночасною мінімізацією витрат матеріальних ресурсів; 3) розширення можливостей користувача у визначенні вмісту легкогідролізованого азоту у грунті без тривалих хімікоаналітичних досліджень за рахунок вибору регресійних рівнянь, отриманих на основі використання базових показників фізичних та хімічних властивостей грунтів певного типу та підтипу, згідно з наявною інформацією; 4) універсальність способу завдяки придатності встановлених залежностей запропонованого способу для 
грунтів всіх типів і підтипів та природно-кліматичних зон і забруднювачів.

\section{Матеріали та методи досліджень}

Розроблення способу включало:

1) проведення патентного пошуку (DSTU 3574, DSTU 3575) за опрацювання патентної документації, формулювання робочої гіпотези (ідеї). Об'єкти патентного пошуку - об'єкти авторського права, які запатентовано в Україні та країнах пострадянського простору, ЄС в площині поставленої мети. Предмет пошуку - спосіб у цілому; окремі операції (етапи) способу, що є самостійним патентоспроможним об'єктом; способи їх одержання i галузь застосування; обладнання, що використовують при здійсненні способу; методичні підходи щодо прогнозування елементного статусу грунтів різних типів, у тому числі i за техногенного забруднення ВM i технологічного навантаження, за використання методів математичного моделювання для прогнозу стану грунтів як компонентів довкілля; методи екстраполяції та експертних оцінок. Методи досліджень - методи теоретичного аналізу, системний підхід;

2) польовий етап - грунтово-геохімічні дослідження, у тому числі за умов технологічного навантаження на грунти різних типів та за умов сталого впливу джерел атмотехногенних емісій забруднення неорганічної природи Харківської області і промислових об'єктів Донецької області та проведення серії стаціонарних мікропольових дослідів. Об'єкти дослідження - грунти Полісся, Лісостепової і Степової природно-кліматичних зон України за впливу забруднення ВМ та за його відсутності. Методи досліджень - універсальні загальнонаукові методи, екосистемний та ландшафтно-геохімічні підходи.

Дослідження закономірних зв'язків макроелементного, гумусового і енергетичного стану грунтів різного генезису та відповідно показників грунтових властивостей було проведено із відбором зразків з орного (до 20 см) шару.

Ірунтово-геохімічні дослідження щодо техногенного навантаження ВМ на грунт проводили за умов сталого та періодичного впливу джерел поліелементного забруднення Зміївської ТЕС ПАТ «Центренерго» НАК «Енергетична компанія України» Харківської області, ВАТ «Укрцинк» і ВАТ «Авдіївський коксохімічний завод» Донецької області. Також для підтвердження ідеї за розробки нового технічного рішення було використано цифрові матеріали щодо вмісту ВМ у грунтах 3 Екологічних атласів Харківської (2005), Донецької (2007) областей.

Польові стаціонарні дослідження щодо технологічного навантаження проводили в Харківській області з вивчення ефективності впливу органо-мінеральної, органічної та мінеральної систем удобрення у встановленій ефективній кількості співвідношення комбінації грунтополіпшувачів із відбором грунтових зразків та встановленням закономірностей змін вмісту сполук азоту грунту на чорноземі типовому важкосуглинковому. Досліди закладено в 1969 р. на Слобожанському дослідному полі ННЦ ІГА Харківського району Харківської області. Протягом 1969-1983 рр. триразовим внесенням високих доз мінеральних добрив (200, 400 і 600 кг/га д.р.) було створено чотири рівні (природний, середній, підвищений, високий) азотних, фосфорних, калійних i азотнофосфорно-калійних агрохімічних фонів. На створених фонах було закладено дрібноділянкові досліди, повторність їх варіантів - триразова.

Також було використано створену інформаційну базу даних відділу агрохімії ННЦ ІГА, що містить дані літературних джерел, які характеризують родючість основних типів грунтів України відповідно до природнокліматичних зон Полісся, Лісостепу і Степу.

Енергоємність чорноземних грунтів різного гранулометричного складу за впливу систем удобрення визначено в довгострокових польових дослідженнях у Київській (Миронівська ДС), Харківській (ДП Граково), Полтавській (Полтавська ДС) та Луганській (Луганська ДС) областях. Застосовували мінеральну, органічну та органо-мінеральну системи удобрення, які було збалансовано за внесенням основних елементів живлення, а внесення органічних і мінеральних добрив оптимальними дозами проводили за використання чинних методичних рекомендацій (Vlasiuk, Dmytrenko, 1962), відповідно до типу грунту i природно-кліматичних умов певної зони (Dobryva ta yikh vykorystannia, 2010);

3) аналітичний етап - у зразках грунтів різних типів (дерново-підзолисті, світло-сірі, сірі, темно-сірі; чорноземи опідзолені, типові, звичайні та південні, каштанові грунти тощо) за лабораторно-аналітичних досліджень згідно 3 чинними ДСТУ та методичною базою визначили: а) загальний уміст органічної речовини - за методом Тюріна (DSTU 4289); б) груповий (за модифікованим методом M. М. Кононової та Н. П. Бєльчикової згідно з DSTU 7855) та фракційний склад гумусу грунту (модифікований метод В. В. Пономарьової та Т. А. Плотнікової згідно з DSTU 7828); в) здійснили препаративне виділення гумусових речовин грунту (DSTU 7606); г) питому енергоємність грунтів і препаратів ГК - за допомогою калориметричної установки $B$ - 08 MA ПУ 1.470 .000 за показником питомої теплоти згорання зразків (DSTU 7866); д) показники щільності будови грунтів за фонових умов, впливу техногенного та технологічного навантаження (DSTU ISO 11272-2001); є) уміст легкогідролізованого азоту - за методом Корнфілда (DSTU 7863) для проведення зіставлення отриманих даних;

4) камеральний етап - прогнозування стану азотних систем грунтів різних типів за експертного оцінювання нормативно-довідкової документації, розрахунок показника загальних запасів енергії гумусу грунту, статистична обробка отриманих даних щодо азотного, гумусового, енергетичного стану грунтів, у тому числі і за впливу технологічного навантаження, техногенного забруднення ВМ за методом побудови математичних моделей.

Розрахунок показника загальних запасів енергії, що акумульовані гумусом грунту, як індикатора енергетичного стану грунту, проводили за відомою формулою Д. С. Орлова - Л. А. Гришиної (Orlov, Grishina, 1981; Orlov et al., 2004) у модифікації О. Л. Орлова (Orlov, 2002), що враховує якісний склад гумусу i теплоємність основних його фракцій:

$$
\mathrm{Q}=(19,96 \Gamma \mathrm{K}+9,16 \Phi \mathrm{\Phi}+17,86 \Gamma 3) \times \mathrm{H} \times \mathrm{d} \times 10 / 100,
$$

де Q - запаси енергії, акумульовані гумусом грунту, $10^{6}$ кДж /га (або $10^{3}$ МДж /га); 19,96 - теплота згорання гумінових кислот, кДж/г; 9,16 - теплота згорання фульвокислот, кДж /г; 17,86 - теплота згорання гуміну, кДж /г; ГК - вміст гумінових кислот, \%; ФК - вміст фульвокислот, \%; ГЗ - вміст гуміну, \%; Н - шар грунту, м;

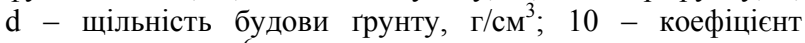
переведення в $10^{6}$ кДж/га; 100 - перерахування одиниць виміру показників умісту ГК, ФК та ГЗ у відсотках.

Аналітичні числові дані щодо акумулятивної енергетичної функції гумусових речовин грунту показників питомої внутрішньої енергії або теплотворної здатності гумусу; запасів енергії, що акумульовані гумусом грунту, макроелементного статусу (за показниками вмісту легкогідролізованого азоту грунту) та гумусового стану статистично обробляли із використанням модулів кореляційного, дисперсійного, регресійного аналізів у рамках пакета Statistica 10.0, включаючи розрахунки за рівняннями лінійної, ступеневої і логарифмічної регресії. 


\section{Результати та їх обговорення}

Розробкою науково-методичного забезпечення дослідження вмісту різних груп сполук азоту грунтів різних типів встановлено, що для вичерпної його характеристики необхідним є визначення загального та легкогідролізованого азоту, нітрифікаційної здатності грунтів, нітратів або суми нітратів і обмінного амонію. Але для діагностування та прогнозування азотного стану грунту показник умісту лабільного легкогідролізованого азоту, поряд із загальним азотом, $є$ найбільш вагомим за рахунок:

1) його численних взаємозв'язків 3 іншими формами азоту грунту (валовою, мінеральними $-\mathrm{NO}_{3}{ }^{-}, \mathrm{NH}_{4}{ }^{+}$тощо) та показниками мікробіологічної трансформації сполук азоту грунту (амоніфікаційна, нітрифікаційна здатність, симбіотична та несимбіотична азотфіксація, денітрифікація тощо);

2) його значного вмісту у грунтах різних типів у порівнянні 3 умістом рухомих мінеральних форм азоту. Вміст легкогідролізованого азоту у грунтах Полісся складає 14-18 \%, у грунтах Лісостепу - 6-10 \% та Степу 16-19\% у порівнянні з умістом мінеральних форм азоту 1,5-2,8\% та 1-2 \% відповідно у грунтах Полісся та Лісостепу і Степу України (Nosko, 2013);

3) встановленого закономірного зв'язку (коефіцієнти кореляції становили $0,82-0,96)$ вмісту легкогідролізованого азоту грунту 3 виносом та вмістом азоту у зерні i вегетативній масі рослин, зокрема пшениці (Triticum durum), кукурудзи (Zea mais L.) та соняшнику (Helianthus annuиs), що важливо для якісного та своєчасного проведення грунтової діагностики азотного живлення рослин i точного визначення та коригування доз застосування азотних добрив та подальшого диференційованого внесення азоту до сівби та в підживлення посівів у весняно-літній період вегетації певної культури по кожному полю;

4) придатності показника для діагностування як азотного стану грунту, так і забезпеченості рослин азотом протягом періоду їх вегетації, у порівнянні з мінеральними формами азоту грунту, кількісний уміст яких коливається в залежності від зволоження грунту та протягом вегетаційного періоду рослин (коливання складають від 10 до 400 кг/га у шарі грунту до 1 м), та характеризують забезпеченість рослин азотом грунту на період його визначення, що значно ускладнює оцінювання та нормування якості грунтів за його вмістом;

5) точності чинних методів визначення легкогідролізованого азоту в грунтах (10-15 \%) як індикатора інтенсивності та спрямованості грунтових процесів.

Таким чином, за результатами проведених досліджень щодо використання показника легкогідролізованого азоту грунту підвищується ефективність його діагностування 3 одночасним забезпеченням більш точного визначення родючості грунту. Показник умісту лабільного легкогідролізованого азоту грунту відображає найближчий його резерв для рослин, що здатний трансформуватись мікроорганізмами у мінеральні форми азоту, доступного рослинам, який складає 3-8\% від загального вмісту азоту у грунтах України (Yurko, 1979).

Визначенням закономірних зв'язків між показниками макроелементного та енергетичного статусу грунтів реалізується можливість оперативного переходу від одних інформативних показників до інших із одночасним більш точним кількісним діагностуванням і оцінюванням інтенсивності грунтових процесів та можливістю прогнозувати стан макроелементних систем грунту певного типу за базовими показниками властивостей, що визначають генетичну приналежність грунту.

Використання показників енергоємності грунтів різного генезису у спряженні з гумусовим станом для визначення макроелементного статусу грунтів обумовлено їх високою інформативністю та прогностичністю внаслідок тісного взаємозв'язку біогеохімії вуглецю та азоту у грунтах різного генезису (Kovda, 1985; Bashkin, 2008), можливістю об'єднання різних показників інтенсивності біологічних процесів грунту (мікробіологічна і біохімічна активність; розкладання, синтез органічних сполук тощо) у єдиних узагальнених показниках його енергетичного стану для коректного визначання спрямованості перетворень речовин i енергії в грунтах різного генезису.

Відомо, що функціонування азотних систем грунтів $\epsilon$ біологічно обумовленим, у зв'язку з чим важко піддається діагностуванню (Bashkin, 1987; Truskavec'kij, 2003). Основним механізмом азотного режиму грунту $є$ спряжене функціонування грунтового мікробіоценозу, кореневої системи рослин як живої фази грунту i колоїдного комплексу грунту. Отже, для діагностування азотного стану грунтів доцільно використовувати співвідношення процесів мобілізації - іммобілізації форм азоту грунту.

Узагальненням проведених багаторічних польових досліджень та аналізуванням отриманих даних щодо вмісту азоту в грунтах різного генезису різних природнокліматичних зон України (Nosko, Yunakova, 1993; Nosko, Merkulova, Babych, 2000; Nosko, 2013; Khrystenko, Hladkikh, Yunakova, 2013) було встановлено пряму залежність між умістом у грунтах України загального азоту i легкогідролізованого азоту (представленого більшою частиною органічними формами), визначеного за методом Корнфілда $(\mathrm{r}=0,86)$.

За результатами досліджень було встановлено порушення співвідношення хімічних елементів у грунті за прояву явищ геохімічного синергізму $\left(\mathrm{N}-\mathrm{NH}_{4} \mathrm{i} \mathrm{Cd}, \mathrm{Pb}, \mathrm{Ni}, \mathrm{Cr} ; \mathrm{N}^{-\mathrm{NO}_{3}} \mathrm{i} \mathrm{Cr}\right.$ ) та антагонізму йонів $\left(\mathrm{N}-\mathrm{NH}_{4}\right.$ i $\mathrm{Cr} ; \mathrm{N}^{-N_{3}}$ i $\left.\mathrm{Cd}, \mathrm{Pb}, \mathrm{Ni}, \mathrm{Cr}\right)$, підвищення вмісту лабільного легкогідролізованого азоту, що значно ускладнюе визначення рівнів умісту азоту забрудненого грунту та знижує точність отриманих даних (Fateev, Samokhvalova, 1999; Samokhvalova, Fateev, 2001). Спосіб, що пропонується, дає можливість отримати коректні дані азотного стану грунту за будь-яких умов: фонових, техногенного забруднення та технологічного навантаження.

Показник умісту лабільного легкогідролізованого азоту грунту, визначений за енергетичними показниками грунтів як інформативний критерій, дає можливість його використання для прогнозування стану азотних систем грунтів різного генезису, оцінювання якості та екологоенергетичного статусу грунту, чим забезпечується технічний результат способу - підвищення точності та експресності визначення лабільного легкогідролізованого азоту як біогенного елементу грунтів різних типів, у тому числі під впливом антропогенних навантажень.

За результатами проведених нами досліджень щодо селективного використання показників стану азотних, вуглецевих та енергетичних систем грунтів встановлено підвищення ефективності прогнозування екологічного стану грунтів використанням показника вмісту лабільного легкогідролізованого азоту грунту, що відображає родючість грунту на рівні типу, екологічні та продукційні функції та характеризує забезпеченість відповідно до градації вмісту в грунті.

Узагальненням отриманих результатів патентних досліджень встановлено існуючі технічні рішення щодо прогнозування екологічних та продукційних функцій грунтів за використання показників умісту макроелементів. Зокрема, відомо спосіб потенціометричного вимірювання фізико-хімічних показників грунту (Pat. na korysnu model' 29958 UA), який здійснюють за допомогою йонселективних електродів, що розміщують у грунті певним чином та по різниці їх потенціалів, які співвідносяться 3 відповідними фізико-хімічними показниками грунту, роблять висновки про ці показники. Спосіб дозволяе точно визначити вміст мінеральних форм азоту in situ в натурних умовах польових досліджень. Однак для одержання точних 
та відтворюваних результатів виконання способу необхідним $\epsilon$ збереження однакових умов експериментів на межі електрод/досліджуваний розчин шляхом вибору оптимальних умов експерименту на всіх стадіях аналізу від пробопідготовки до обробки одержаних даних, що $\epsilon$ досить складним у реалізації внаслідок об'єктивних труднощів пошуку ізопотенціальної точки при роботі із іон-селективними електродами (яка знаходиться за межами калібрувального графіку), або різнобічний зсув потенціалів електроду порівняння та індикаторного електроду зі зміною температури розчину; заниження або завищення результатів аналізу за рахунок впливу йонів $\mathrm{OH}^{-}$та $\mathrm{H}^{+}$ тощо. Недоліком методу $\epsilon$ припущення, що склад аналізованого розчину після градуювання електроду залишається постійним. Як результат, збільшується похибка, пов'язана із корекцією електродної функції. Величини похибок визначення концентрації методом прямої потенціометрії для одно-, два- та тризарядних іонів становлять $\pm 12 \%$.

Наступний відомий спосіб визначення стану азотних систем грунту передбачає визначення його азот-буферних властивостей (Truskavec'kij, 2003). Спосіб включає систему лабораторних досліджень процесів мобілізації та іммобілізації (депонування) мінеральних форм азоту грунту i добрив із охопленням діапазону їх можливих перетворень за серії компостувань неудобреного грунту та внесення доз азотнокислого амонію, 3 подальшим визначенням іонів нітратів і амонію та їх активностей $\mathrm{pNO}_{3}, \quad \mathrm{pNH}_{4}$. За результатами аналізу розраховують кількість іммобілізованого (депонованого) грунтом азоту. Відношення величин внесеного азоту добрив та вмісту його рухомих форм (мінерального азоту) в грунтовому розчині характеризує іммобілізаційну азот-буферну здатність грунту, що діагностується шляхом визначення потенційно можливого накопичення мінеральних форм азоту за рахунок багаторазового циклічного компостування одного i того ж зразку грунту до максимальної втрати ним здатності утворювати ці форми за рахунок мінералізаційних процесів (визначається за відсутністю подальшого накопичення нітратів). Відношення величин вилучених із грунту мінеральних форм азоту та їх зменшення після кожного циклу лабораторного компостування приймається за показник азот-буферної здатності в мобілізаційному (негативному) крилі буферності. Проте недоліками способу слід вважати: 1) його трудомісткість та часовитратність, що унеможливлює використання для масових аналізів; 2) зниження функціональних можливостей його реалізації і відповідно ефективності його застосування внаслідок низького рівня адекватності поведінці азоту в натурних (польових) умовах використання грунтів.

Відомо інший спосіб прогнозування вмісту мікроелементів у грунтах (Pat. na korysnu model 107854 UA), що за встановленням закономірних зв'язків $\mathrm{ME}$ та ВM 3 показниками енергоємності грунту (питома внутрішня енергія гумусу або теплотворна здатність гумусу; загальні запаси енергії у шарі до 20 см) дає можливість отримати дані щодо якості грунтів певного типу. Однак отриманий у способі закономірний зв'язок показників якості грунтів не дає можливості точного визначення і параметризації взаємозв'язку показників без урахування: 1) дії на нього основних макроелементів грунту, що значно впливають на рухомість та транслокацію МЕ/ВМ у суміжні 3 грунтом середовища, ME статус грунтів в цілому; 2) наявності тісного зв'язку між умістом макроелементів у грунтах, а саме того, що 7090 \% азоту грунту (основна частина біогенного елементу) входить до складу специфічних гумусових речовин; 10$30 \%$ - до складу «неспецифічних» органічних речовин; близько $1 \%$ загального вмісту азоту - знаходиться у складі мінеральних солей у грунті (Туurin, 1965), середній уміст азоту складає $1 / 20$ частину вмісту гумусу грунту
(Gamzikov, 1981). Отже, не існує точного прогнозування якості грунтів 3 урахуванням базових показників родючості та основних показників умісту макро- та МЕ грунту.

Найбільш близьким за механізмом реалізації i результатом, що досягається, $\epsilon$ спосіб прогнозування відтворення родючості грунту (Avtor. sv. SU 1481681), заснований на встановленні енергопотенціалу грунту та біомаси рослин методом калориметрії, що передбачає розрахунок за формулою показника відтворення родючості грунту $(\gamma)$ з урахуванням енергопотенціалу грунтів, що вкриті рослинам та без них, за весь період вегетації рослин. За величиною запропонованого показника прогнозують розширене $(\gamma>1)$, просте $(\gamma=1)$ відтворення родючості грунту або його деградацію $(\gamma<1)$. Проте недоліками способу $є$ такі: 1) визначання інтенсивності накопичення та витрат енергії необхідно проводити в грунтах за вегетаційний період вирощування різних видів рослин для отримання відповідних показників, що значно збільшує трудомісткість і часовитратність реалізації способу; 2) згідно із способом прогноз розширеного відтворення родючості грунту $\epsilon$ можливим за умови надходження в грунт всієї біомаси рослин, що практично $є$ нездійсненим та потребує урахування іï відчуження, що збільшує похибку способу; 3) спосіб дозволяє прогнозування родючості лише для грунтів, приріст енергопотенціалу яких за вегетаційний період буде не менше 1 \% вихідної величини, що звужує можливості його застосування; 4) обмеженість або неможливість використання способу внаслідок мінімуму інформації у користувача щодо енергопотенціалу грунтів та можливостей ii отримання, що потребує значних витрат матеріальних ресурсів та часу за обов'язкового урахування всіх «носіїв» енергії грунту.

Для підвищення точності прогнозування родючості грунтів різного генезису необхідно додаткове встановлення закономірних зв'язків показників якості грунтів за показниками вуглецевого (гумусового) стану, енергетичного та азотного стану.

Розроблений алгоритм нами запропонованого методичного підходу включає: відбір зразків із орного (до 20 см) шару грунтів різного генезису, зокрема акумулятивного ряду, лабораторно-аналітичні дослідження згідно 3 чинними нормативними документами та методичною базою 3 визначенням таких показників: 1) загальний умісту гумусу; 2) груповий та фракційний склад гумусу грунту; 3) препаративне виділення гумусових речовин грунту та визначення питомої енергоємності грунтів і препаратів ГК (гумінових кислот) - за показником питомої теплоти згорання зразків за використанням калориметричної установки; 4) вміст легкогідролізованого азоту для проведення зіставлення отриманих даних. Всі отримані результати та відомі довідкові дані показників властивостей грунту певного типу вносимо в табл. 1.

Далі розраховують показник загальних запасів енергії, що акумульовані гумусом грунту, як індикатора його енергетичного стану, за відомою формулою Орлова. Отримані результати розрахунку показника енергоємності грунту за формулою також вносимо в табл. 1 та використовуємо як базову для подальших розрахунків залежностей умісту легкогідролізованого азоту, показників гумусового стану та енергоємності грунтів (теплотворна здатність гумусу, запаси енергії грунту у шарі до 20 см) за фонових умов, технологічного навантаження i техногенного забруднення ВМ з одержанням відповідних регресійних рівнянь залежностей після статистичної обробки (кореляційний, дисперсійний, регресійний аналіз) даних за подальшої візуалізації результатів на діаграмах (рис. 1, $a-б)$. На основі отриманих регресійних рівнянь, зокрема для акумулятивного ряду грунтів, визначаємо прогнозовані значення вмісту лабільного легкогідролізованого азоту у грунтах різного генезису: 


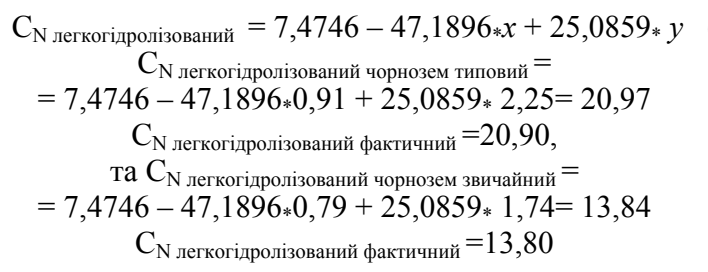

розрахунку стандартної похибки оцінки, яка для показника $\mathrm{C}_{\mathrm{N} \text { легкогідролізований }}-1,30$; це підтверджує високу точність розрахункових значень умісту азоту в чорноземних грунтах.

Окрім того, для підтвердження достовірності отриманих розрахункових даних було додатково на тих самих грунтах проведено визначення фактичного вмісту

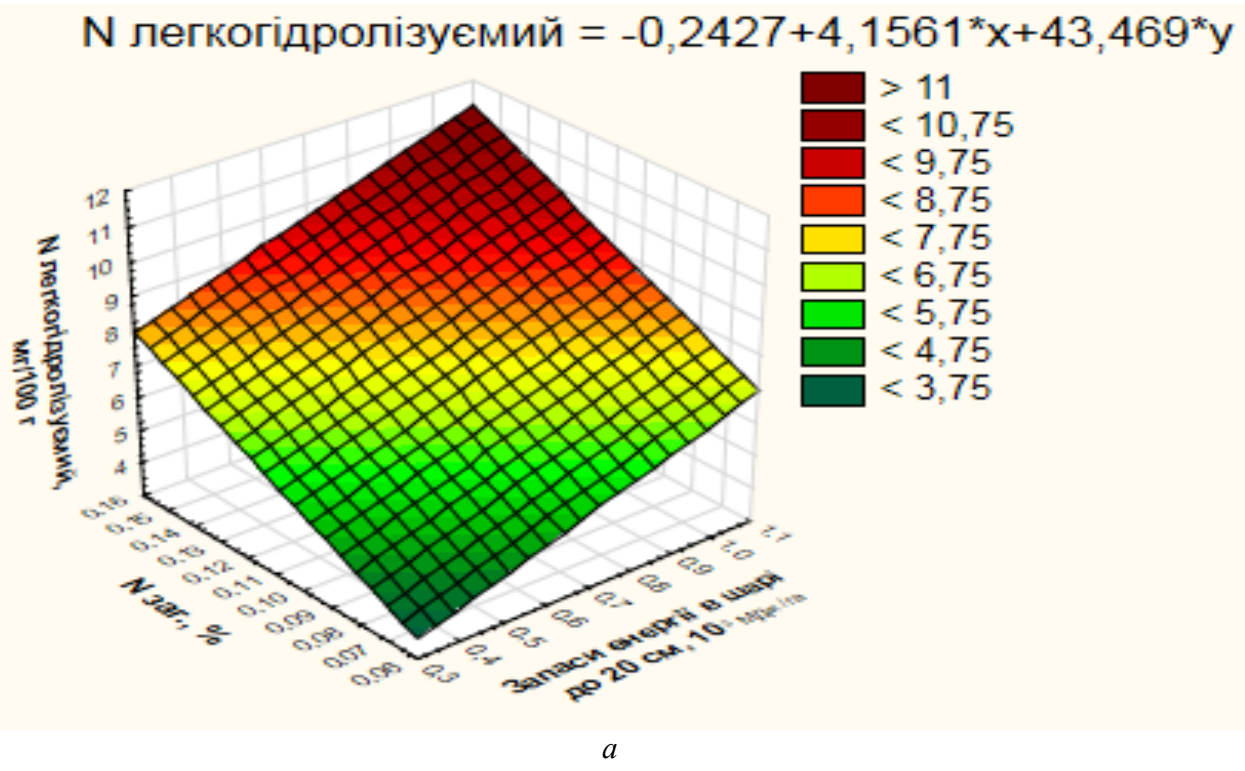

Теплотворна здатність гумусу $=-0,2194+0,822^{*} \mathrm{x}-0,0024^{\star} \mathrm{y}$

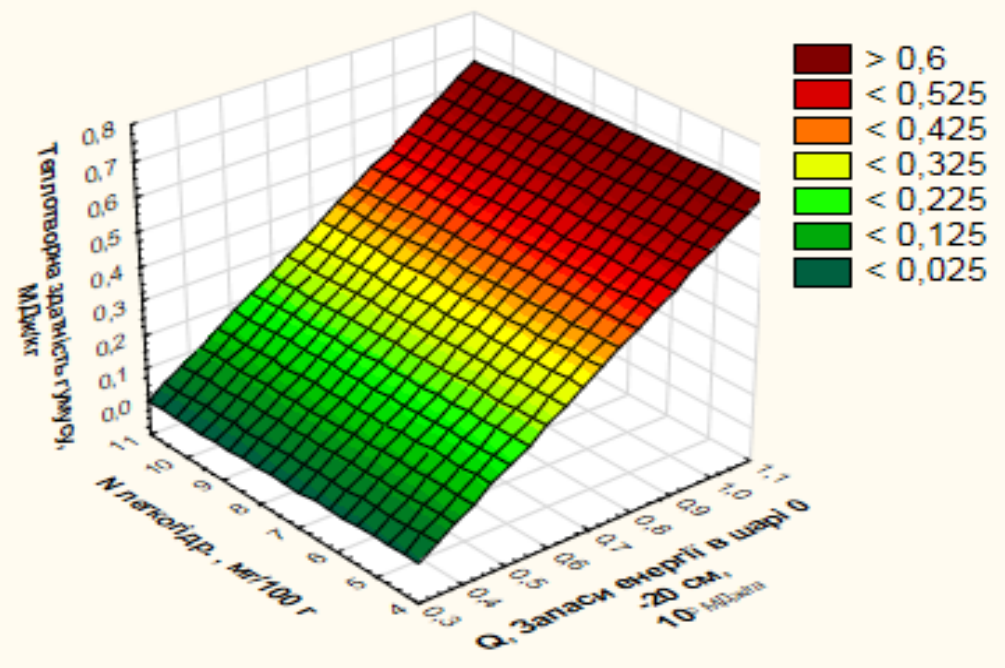

6

Рис. 1. Візуалізовані моделі встановлених залежностей показників енергетичного стану грунту та рівнів умісту легкогідролізованого азоту

лабільного легкогідролізованого азоту за Корнфілдом згідно 3 чинними нормативно-методичними документами (точність методу $\pm 15 \%$ ). Результати зіставлення отриманих розрахункових даних із даними фактичного вмісту азоту в грунтах свідчать про високу їх відповідність та точність (табл. 2).

Результатами проведення досліджень щодо визначення показника вмісту легкогідролізованого азоту в

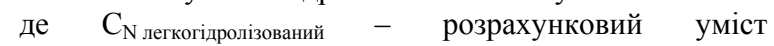
легкогідролізованого азоту грунту, мг/100 г грунту;

$x$ - теплотворна здатність гумусу грунту, МДж / кг;

$y$ - запаси енергії в шарі до 20 см грунту певного типу, $10^{3}$ МДж /га

3 одночасним визначенням точності отриманих числових значень прогнозованого вмісту азоту в грунті за найбільш поширених в Україні грунтах різних типів та підтипів (табл. 2) було підтверджено універсальність запропонованого алгоритму способу та його ефективність для точного прогнозування стану азотних систем грунтів різного генезису, що об'єднані в ряди за ознакою переважання грунтового процесу, наприклад грунти опідзоленого ряду (процес опідзолення) - дерново-підзолисті, ясно-сірі, сірі опідзолені та темно-сірі тощо; акумулятивного ряду (дерновий процес) - чорноземи типові, звичайні і південні тощо. Зокрема, розрахункові величини вмісту легкогідролізованого азоту в чорноземних грунтах за фонових умов становили 13,8-20,9 мг/100 г грунту; за техногенного забруднення $\mathrm{BM}-13,2-13,6 \quad$ мг/100 г грунту; за технологічного навантаження - 12,4 мг/100 г грунту. Таким чином, отримуємо дані щодо стану азотних систем грунтів різного генезису з урахуванням рівнів їхньої енергоємності. 


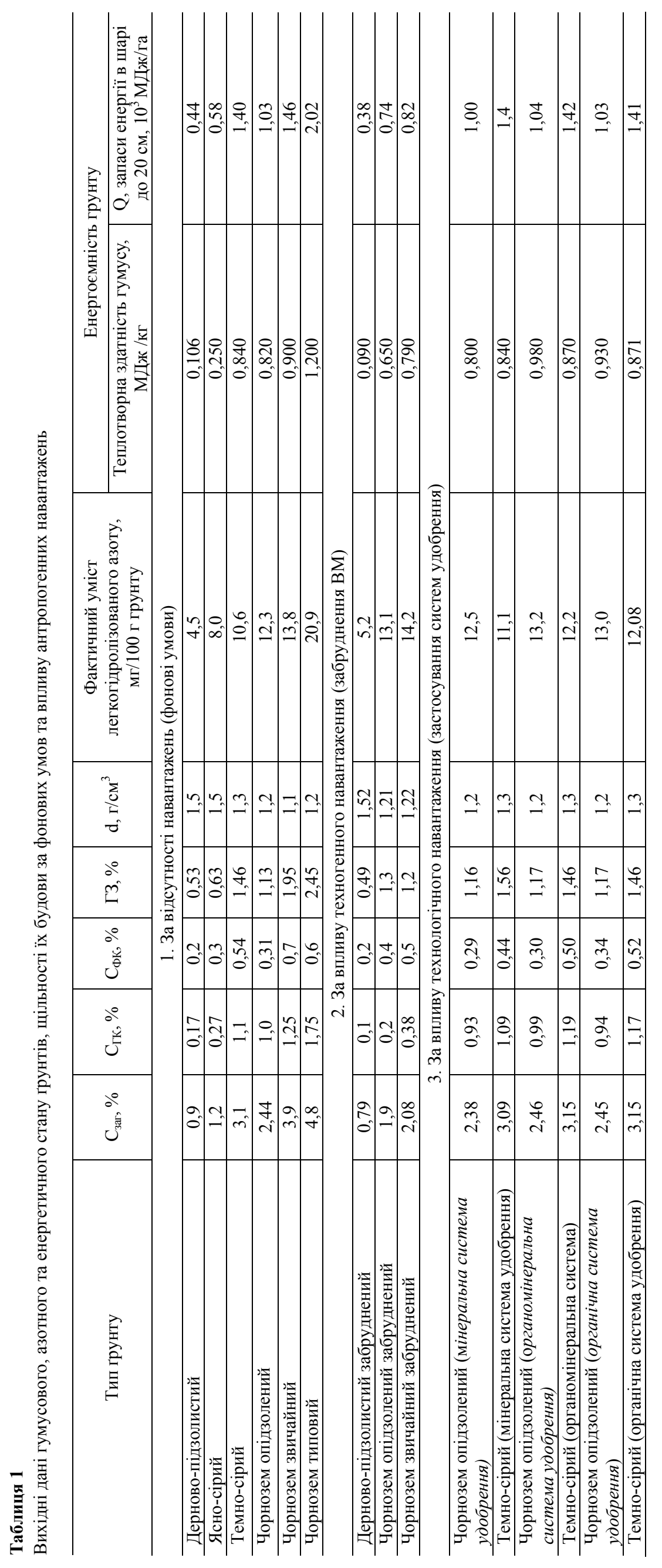



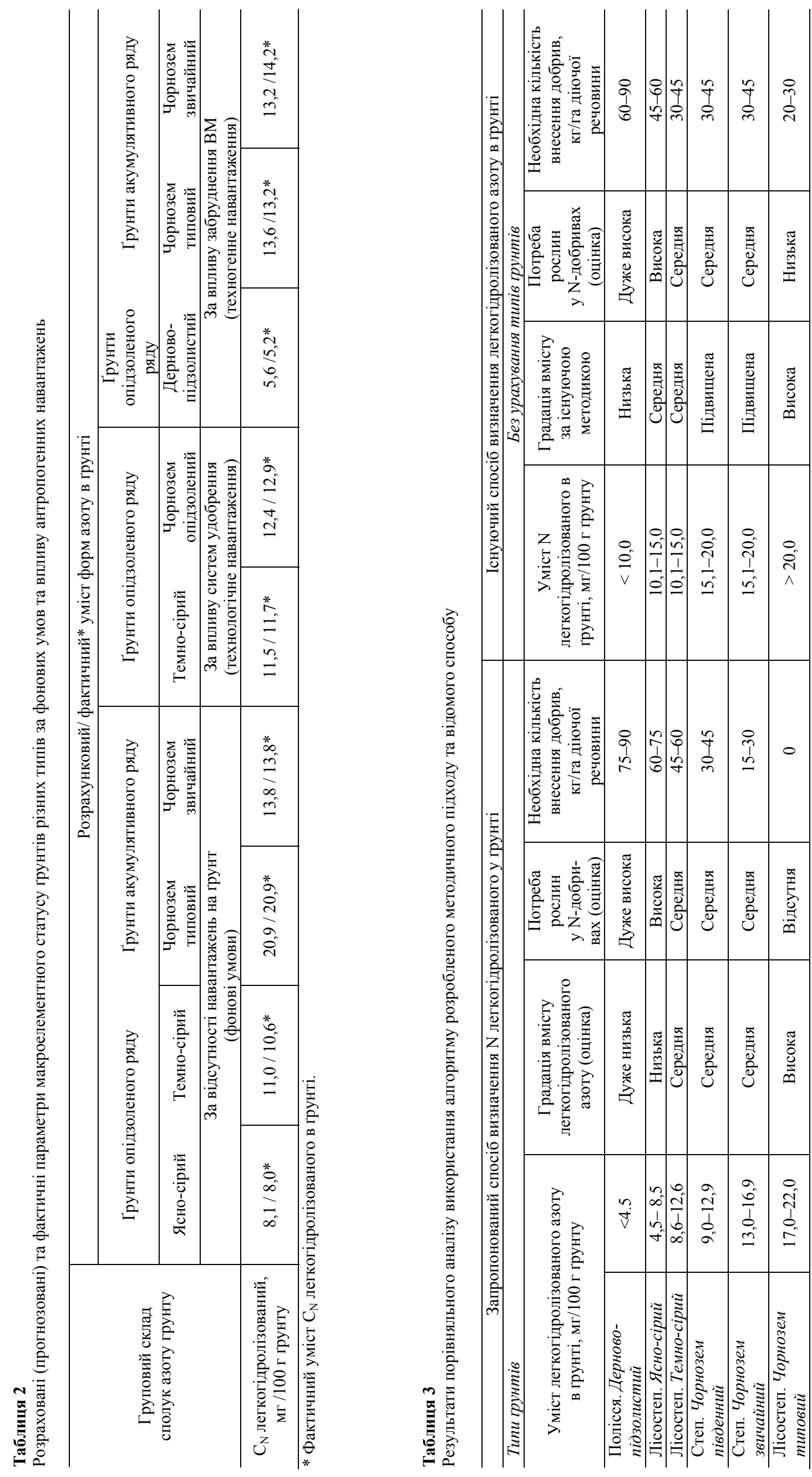
Одночасно забезпечується можливість оцінювання еколого-енергетичного стану грунтів за вирішення зворотної задачі розрахунку кількісних параметрів одного показника на підставі кореляційно пов'язаних 3 ним відомих інших (рис.1, а-б). Тобто запропоноване рішення розширює та полегшує можливості користувача у визначенні вмісту лабільного легкогідролізованого азоту в грунті без тривалих хіміко-аналітичних досліджень за рахунок вибору відповідних математичних рівнянь, отриманих на основі наявних даних.

Для оптимізації режиму макроелементного живлення рослин, за рахунок поживних речовин грунту та застосування різних форм і способів внесення органомінеральних добрив, необхідно враховувати вплив на цей процес різних чинників, а саме: рівень забезпеченості грунту поживними речовинами, зокрема азотом; біологічні особливості рослин, асиміляцію азоту з повітря тощо, які ускладнюють розрахунки норм мінеральних добрив під прогнозовану врожайність рослин, що призводять до розбіжностей у рекомендаціях розрахункових норм азотних добрив для внесення, та підвищення витрат матеріальних ресурсів та, відповідно, ціни на кінцеву рослинну продукцію, а також збільшує ризики забруднення азотними сполуками системи грунт - рослина та суміжних середовищ. Також запропонований спосіб забезпечує ефективне проведення грунтової діагностики азотного живлення рослин і нормування вмісту азоту в грунтах шляхом дозування внесення добрив 3 одночасним урахуванням їх генетичних особливостей. Одночасно реалізується можливість точного визначення та коригування доз застосування азотних добрив для подальшого диференційованого внесення азоту у грунт.

Спосіб дозволяе оцінити якість грунтів різного генезису за вмістом азоту за умов активізації або зниження інтенсивності малого біологічного кругообігу сполук елементів i енергії грунту (зволоженість грунту, антропогенні навантаження) для подальшого розроблення екологічних вимог до забруднення рослин як критеріїв для обгрунтування нормативних показників умісту біогенних елементів, зокрема азоту та вуглецю, максимально допустимого вмісту рухомих сполук азоту в системі грунт добриво - рослина - вода.

\section{Висновки}

Розроблено методичний підхід щодо прогнозування стану азотних систем грунтів на прикладі визначення вмісту біогенного легкогідролізованого азоту в грунтах різних типів за фонових умов, впливу технологічного навантаження та ризику i наявності техногенного забруднення ВМ, який захищено охоронним документом (Pat. na korysnu model 122345 UA, 2018 р.). За рахунок встановлення нових взаємозв'язків показників енергоємності грунтів (теплотворна здатність гумусу, запаси енергії грунту в шарі до 20 см) у спряженні 3 гумусовим станом та використанням математикостатистичного аналізу отримують регресійне рівняння визначення величини легкогідролізованого азоту 3 можливістю прогнозування якості грунтів різного генезису, з поширенням алгоритму способу на грунти різних типів певної природно-кліматичної зони за умов техногенного забруднення і технологічного навантаження.

Технічний результат способу: за рахунок удосконалення визначення рівнів умісту легкогідролізованого азоту в грунтах різного генезису для оцінювання їх якості шляхом визначення найбільш кореляційно пов'язаних, діагностично придатних інтегральних базових показників грунтових властивостей, які дозволяють своєчасно, 3 підвищеною точністю, експресністю та інформативністю приймати управлінські рішення, та прогнозувати якість грунтів різного генезису за вмістом легкогідролізованого азоту як біогенного елементу за фонових умов та антропогенних навантажень.

Відмінними рисами та перевагами запропонованого методичного підходу, у порівнянні з відомими способами та підходами, є такі: 1) експресність отримання точних прогнозованих рівнів умісту легкогідролізованого азоту як біогенного елементу у грунті 3 підвищенням точності грунтової діагностики за рахунок використання базових інтегральних показників; 2) забезпечення можливості отримання більшої результативності прогнозованих даних щодо функціонування азотних систем грунтів різного генезису, якості та еколого-енергетичного стану грунтів, за фонових умов та антропогенних навантажень 3 одночасною мінімізацією витрат матеріальних ресурсів; 3) розширення можливостей користувача у визначенні вмісту легкогідролізованого азоту в грунті без тривалих хіміко-аналітичних досліджень за рахунок вибору регресійних рівнянь, отриманих на основі використання базових показників властивостей грунтів певного типу та підтипу, згідно з наявною інформацією; 4) універсальність способу завдяки придатності встановлених залежностей запропонованого способу для грунтів всіх типів і підтипів та природно-кліматичних зон і забруднювачів.

Новий методичний підхід може знайти застосування в оцінюванні та екологічному нормуванні якості грунтів за вмістом ME, нормуванні навантажень (техногенних, технологічних) на грунтову систему, агроекології 3 вирішення питань моніторингу родючості грунтів, паспортизації земель різного призначення та використання; органічного землеробства, біоенергетики i енергетики грунтоутворення; діагностики, оцінювання, визначення якості гумусу i статусу ME, небезпеки надлишкового накопичення ВМ у грунтах за показниками елементного, гумусового та/або енергетичного стану; екологічного менеджменту грунтів як за фонових умов, так i за різних антропогенних впливів, та в науково-дослідній практиці 3 дослідження біогеохімії i біогенних макроелементів грунтів.

Окремі положення розробленого способу стали складовою пропозицій, поданих у 2017 р. до Міністерства екології та природних ресурсів України, де опрацьовувались матеріали 3 адаптації до Нітратної Директиви Ради ЄС 91/676/ЄЕС від 12.12.1991 р. про захист вод від забруднення, спричиненого нітратами 3 сільськогосподарських джерел, із змінами і доповненнями, внесеними Регламентом ЄС №1882/2003 Cross Nitrogen Balances Handbook (лист № 575/1-04 від 23.06.2017).

Подані пропозиції, що наведені нижче, пропонується розглядати як перспективні напрями подальших досліджень за тематикою діагностування, оцінювання, прогнозування стану азотних систем грунтів та нормування якості за елементним складом, зокрема вмістом біогенного азоту.

1. Розробкою науково-методичного забезпечення дослідження вмісту різних груп сполук та фракцій азоту грунтів різних типів встановлено, що для вичерпної його характеристики необхідним $\epsilon$ визначення загального та легкогідролізованого азоту, нітрифікаційної здатності грунтів, нітратів або суми нітратів і обмінного амонію. Для більш ефективного діагностування та прогнозування азотного стану грунту показник умісту лабільного легкогідролізованого азоту, поряд із загальним азотом, $\epsilon$ найбільш вагомим за рахунок:

a) його численних взаємозв'язків 3 іншими формами азоту грунту (валовою, мінеральними $-\mathrm{NO}_{3}{ }^{-}, \mathrm{NH}_{4}^{+}$тощо) та показниками мікробіологічної трансформації сполук азоту грунту (амоніфікаційна, нітрифікаційна здатність, симбіотична та несимбіотична азотфіксація, денітрифікація тощо);

б) його значного вмісту в грунтах різних типів у порівнянні з умістом рухомих мінеральних форм азоту; 
в) встановленого закономірного зв'язку вмісту легкогідролізованого азоту грунту 3 виносом та вмістом азоту у зерні і вегетативній масі рослин, що важливо для якісного та своєчасного проведення грунтової діагностики азотного живлення рослин $\mathrm{i}$ точного визначення та коригування доз застосування азотних добрив та подальшого диференційованого внесення азоту до сівби та в підживлення посівів у весняно-літній період вегетації певної культури по кожному полю;

г) придатності показника для діагностування як азотного стану грунту, так і забезпеченості рослин азотом протягом періоду їх вегетації, у порівнянні з мінеральними формами азоту грунту, кількісний уміст яких коливається залежно від зволоження грунту та протягом вегетаційного періоду рослин, та характеризують забезпеченість рослин азотом грунту на період його визначення, що значно ускладнює оцінювання та нормування якості грунтів за його вмістом;

д) точності чинних методів визначення легкогідролізованого азоту в грунтах (10-15\%) як індикатора інтенсивності та спрямованості грунтових процесів.

2. Урахування інтегрального показника енергоємності грунтів - теплотворної здатності гумусу та запасів енергії до 20 см грунту. Енергоємність грунту $\epsilon$ показником потенційної продуктивності грунту, що тісно пов'язана 3 властивостями грунтів, які визначають рухомість та рівень умісту біогенних макроелементів (N, C, P) та $\mathrm{ME} / \mathrm{BM}$ у грунтах різних типів за фонових (природних) умов, техногенного забруднення та технологічного навантаження. Використання узагальнюючих енергетичних характеристик функціонування грунтової системи дозволяє отримати точні прогнозні дані щодо якості грунту певного типу (елементний статус, якість гумусу як акумулятора і джерела енергіï, енергетичний стан) для оцінювання їх екологічних та продукційних функцій, екологічного нормування якості грунтів різних типів; здійснювати управління відтворенням енергетичного потенціалу їх органічної речовини та якістю.

3. Урахування основного механізму функціонування азотного режиму грунтів різного генезису - спряженого функціонування колоїдного комплексу грунту, грунтового мікробіоценозу та кореневої системи рослин як живої фази грунту та біологічної обумовленості функціонування азотних систем грунтів.

4. Використання співвідношення процесів мобілізації іммобілізації форм азоту грунту в системі грунт мікроорганізми та ферменти - ризосфера рослин.

5. Для діагностування азотного режиму грунтів доцільно використовувати вплив макро- та мікроелементного складу грунтів на біохімічні властивості мікроорганізмів азотного циклу грунту та біологічну активність грунту, що пов'язана 3 розкладанням органічних речовин грунту 3 утворенням аміаку (амоніфікації), процесами нітрифікації та азотфіксації (симбіотичної та несимбіотичної). Недостатня увага до мікробіологічного фактору трансформації азоту в грунті сучасних агроценозів є однією із причин незбалансованого забезпечення рослин азотом, надмірного накопичення нітратів у рослинній продукції, низької ефективності використання азотних мінеральних добрив, забруднення біосфери сполуками азоту з порушенням біогеохімічного циклу азоту (масоване виділення в атмосферу закису азоту $\mathrm{N}_{2} \mathrm{O}$; міграція нітратів 3 добрив та органічної речовини грунту за іiі дегуміфікації в грунтові води). Вивчення динаміки зміни азотного фонду та мікробіологічних процесів трансформації азоту необхідно для розробки практичних заходів, спрямованих на оптимізацію азотного режиму в агроекосистемах, що підвищить біопродуктивність грунтів та забезпечить збереження довкілля.

6. Розроблення Технічного регламенту (нормативноправовий акт) щодо екологобезпечного використання азотовмісних добрив в землеробстві, який регламентуватиме технологічні прийоми використання азотовмісних добрив, що дозволяють звести до мінімуму евтрофікацію поверхневих вод, 3 урахуванням умов основних природних зон України i біологічних особливостей культур; строки, дози і способи екологічно безпечного внесення мінеральних i органічних добрив залежно від рельєфу поля, близькості водоймищ, гранулометричного складу грунтів; співвідношення в сівозмінах багаторічних трав і просапних культур; заходи, спрямовані на захист грунтів від ерозї̈; використання інгібіторів нітрифікації, використання азотовмісних добрив на меліорованих землях, зокрема зрошуваних, методи вимірювання тощо.

7. 3 метою подолання біогенного забруднення, зокрема надмірного накопичення сполук азоту у довкіллі (рослинах, водах), нормування вмісту азоту в грунтах різного генезису має передбачати: а) визначення максимально допустимих рівнів умісту рухомих мінеральних форм нітратного азоту за розробки екологічних вимог до забруднення нітратами рослинної продукції; б) нормування вмісту лабільного легкогідролізованого азоту та/або дози азотних добрив за умов достатнього та надмірного зволоження, ураховуючи швидкі процеси трансформації сполук азоту в грунтах; в) нормування вмісту мінеральних сполук азоту грунту за умов недостатнього зволоження та уповільнення процесів кругообігу азотних сполук грунту.

Автори висловлюють щчиу подяку патентному повіреному ННЦ «ГГА імені О. Н. Соколовського» науковому співробітнику B. М. Горякіній за ефективне сприяння та дієву допомогу в підготовці документаџії щуодо розроблення нового технічного рімення та його інформаційноаналітичного супроводження; співробітникам лабораторіі агрохімї ННЦ «ІГА імені О. Н. Соколовського»-науковому співробітнику Т. А. Юнаковій за консультативну допомогу щуодо методів визначення сполук азоту трунтів, провідному інженеру Корецькій Л. К. за допомогу в аналізуванні зразків трунтів, забруднених важкими металами.

\section{References}

Avtor. sv. SU 1481681 (1989). Sposob prognozirovaniya vosproizvodstva plodorodiya pochvy [The method for predicting of soil fertility reproduction]. V. M. Volodin, A. E. Fedorchenko, L. I. Biryukova, R. F. Eremina, №1481681; appl. 12.02.1987; publ. 23.05.1989, Byul. 19 (in Russian).

Bashkin, V. N. (1987). Agrogeohimiya azota [Agrogeochemistry of nitrogen]. ONTI NCBI, Pushchino. (in Russian).

Bashkin, V. N. (2008). Biogeohimiya [Biogeochemistry: scientific edition]. Vysshaia. Shkola, Moscow (in Russian).

Dobryva ta yikh vykorystannia (2010). [Fertilizers and their use: A Handbook]. Aristey, Kyiv (in Ukrainian).

Fateev, A. I., Samokhvalova, V. L. (1999). Supply of nitrogen in agricultural cultures in condition of polyelement pollution of soil by the heavy metals. Collection of Papers by Ukrainian Members of ESSC, Kharkiv, 42-46.

Gamzikov, G. P. (1981). Azot v zemledelii Zapadnoj Sibiri [Nitrogen in the Agriculture of Western Siberia]. Nauka, Moscow (in Russian).

Khrystenko, A. O., Hladkikh, Ye. Yu., Yunakova, T. A. (2013). Otsinka azotnoho stanu gruntiv i rivnya zabezpechenosti roslyn azotom khimichnymy metodamy [Assessment of the nitrogen state of soils and the level of plant nutrition by nitrogen chemical methods]. Visnyk ahrarnoyi nauky, 12, 17-20 (in Ukrainian).

Kovda, V. A. (1985). Biogeohimiya pochvennogo pokrova [Biogeochemistry of soil cover]. Nauka, Moscow (in Russian).

Mishustin, E. N. (1979). Krugovorot i balans azota v sisteme pochva - udobrenie - rastenie - voda [Rotation and 
balance of nitrogen in the soil - fertilizer - plant - water system]. Nauka, Moscow (in Russian).

Mockler, E. M., Deakin, J., Archbold, M., Daly, D., Bruen, M. (2016). Nutrient load apportionment to support the identification of appropriate water framework directive measures. Biology and Environment - Proceedings of the Royal Irish Academy, 3, 245-263.

Nosko, B. S. (2013). Azotnyy rezhym gruntiv i yoho transformatsiya $\mathrm{V}$ ahroekosystemakh [The Nitrogen Regime and its transformation in the Agroecosystems]. Mis'kdruk, Kharkiv (in Ukrainian).

Nosko, B. S., Merkulova, E. L., Babych, E. V. (2000). Vynos elementov pytanyya ozymoy pshenytsey yz chernozema typychnoho $\mathrm{v}$ zavysymosty ot systemb udobrenyy [Carrying out of trophic elements by a winter wheat from chernozem typical depending on system of fertilizers]. Ahrokhymyya, 2, 45-53 (in Russian).

Nosko, B. S., Yunakova, T. A. (1993). Ahrokhymycheskaya y ahroekolohycheskaya otsenka effektyvnosty udobrenyy na chernozeme typychnom [Agrochemical and agroecological assessment of the fertilizers effectiveness on chernozem typical]. Ahrokhymyya, 3, 61-67 (in Russian).

Orlov, D. S. (1990). Gumusovye kisloty pochv i obshchaya teoriya gumifikacii [Soils humus acids and general theory of humification]. MGU, Moscow (in Russian).

Orlov, D. S. (2005). Himiya pochv [Soil chemistry]. Nauka, Moscow (in Russian).

Orlov, D. S., Birjukova, O. N., Rozanova, M. S. (2004). Dopolnitelnye pokazateli gumusnogo sostojanija pochv i ih geneticheskih gorizontov [Additional indicators of the humus status of soils and their genetic horizons]. Eurasian Soil Science, 8, 918-926 (in Russian).

Orlov, D. S., Grishina, L. A. (1981). Praktikum po himii gumusa [Workshop on humus chemistry]. MGU, Moscow (in Russian).

Orlov, O. L. (2002). Enerhoiemnist yak kryteriy humusovoho stanu gruntiv [Energy intensity as a criterion of soil humus]. Bulletin of Lviv NU. Biology Series, 31, 111-115 (in Ukrainian).

Pat. na korysnu model' 107854 UA (2016). Sposib prohnozuvannya rivniv vmistu mikroelementiv i vazhkykh metaliv gruntiv riznoho henezysu dlya otsinyuvannya yikh ekolohichnykh ta produktsiynykh funktsiy [The method of prognosis the levels of microelements and heavy metals content in soils of different genesis for the estimation of them ecological and productional functions]. V. L. Samokhvalova, Ye. V Skryl'nyk, L. M. Shedey, V. I. Lopushnyak, N. V. Oliynyk, P.A. Samokhvalova, O. V. Mandryka, № u201512399; appl. 15.12.2015; publ. 24.06.2016, Byul. 12 (in Ukrainian).

Pat. na korysnu model 120082 UA (2017). Sposib prohnozuvannya rodyuchosti gruntiv za yikh makroelementnym stanom [The method of soil fertility forecasting by their macroelement state]. V. L. Samokhvalova, A. O. Khrystenko, L. O. Shedey, P. A. Samokhvalova, O. V. Karatsyuba, № u201703324; publ. 25.10.2017; Byul. 20 (in Ukrainian).

Pat. na korysnu model 122345 UA (2018). Sposib viznachennya vmistu legkogidrolizuemogo azotu u gruntah riznogo genezisu dlya otsinyuvannya yakosti gruntiv [The method of determination of easily hydrolysable nitrogen content in soils of different genesis for the estimation of soils quality]. V. L. Samokhvalova, A. O. Khrystenko, L. O. Shedey, P. A. Samokhvalova, O. V. Karatsyuba, № u201707167; publ. 10.01.2018; Byul. 1 (in Ukrainian).

Pat. na korysnu model' 29958 UA (2008). Sposib potentsiometrychnoho vymiryuvannya fizyko-khimichnykh pokaznykiv gruntiv [The method of the potentiometer measuring of soils physical and chemical indexes]. N. F. Cheshko, Yu. L. Tsapko, V. M. Kalinichenko, № u200702858; publ. 11.02.2008, Byul. 3 (in Ukrainian).
Pat. na vynakhid 115014 UA (2017). Sposib vyznachennya vmistu svyntsyu u gruntakh riznoho henezysu dlya otsinyuvannya yikh ekoloho-enerhetychnoho stanu [The method of determination of lead content in soils of different genesis for the estimate of their ecology and energy state]. V. L. Samokhvalova, V. P. Filatov, V. M. Horyakina, № 201612732; publ. 28.08.2017, Byul. 16 (in Ukrainian).

Patentni doslidzhennya. Osnovni polozhennya ta poryadok provedennya [Patent researches are the Substantive provisions and order of realization]. DSTU 3575-97. [Chynnyj vid 1998.01.01.]. Kyiv: Derzhstandart Ukrayiny, 1998. 16 s. (Nacionalnyj standart Ukrayiny) (in Ukrainian).

Patentnyj formulyar. Osnovni polozhennya. Poryadok skladannya ta oformlennya [Patent formular. Substantive provisions. Order of stowage and registration]. DSTU3574-97. [Chynnyj vid 1998.01.01.]. Kyiv: Derzhstandart Ukrayiny', 1998. 14 s. (Nacionalnyj standart Ukrayiny) (in Ukrainian).

Samokhvalova, V. L., Fateev, A. I. (2001). Vozdejstvie poliehlementnogo zagryazneniya pochvy tyazhelymi metallami na balans azota $\mathrm{v}$ sisteme udobrenie - pochva rastenie [The effect of polyelement contamination of soil by heavy metals on the nitrogen balance in the fertilizer soil - plant system]. Kn. 3, Minsk, 164-166 (in Russian).

Samokhvalova, V. L., Skrylnyk, Y. V., Lopushniak, V. I., Shedey, L. O., Samokhvalova, P. A. (2016). Prediction the levels of chemical elements content in soils of different genesis for the assessment of their eco-energy status. Gruntoznavstvo, 17 (3-4), 23-42.

Samokhvalova, V. L., Skrylnyk, Ye. V., Shedey, L. M., Lopushniak, V. I., Samokhvalova, P. A. (2016). Prohnozuvannya rivniv vmistu mikroelementiv i vazhkykh metaliv u gruntakh riznoho henezysu dlya otsinyuvannya yikh ekolohichnykh ta produktsiynykh funktsiy [Prognosis of the levels of microelements and heavy metals content in soils of different genesis for the evaluation of them ecological and productional functions]. Ekology and Noospherology, 27(1-2), 72-87 (in Ukrainian).

Savich, V. I., Syichev, V. G., Nikolskiy, Yu. V., Zamaraev, A. G., Syunyaev, N. K. (2007). Energeticheskaya otsenka plodorodiya pochv [Energy assessment of soil fertility]. VNIIA, Moscow (in Russian).

Schepers, J. S., Raun, W. R. (2008). Nitrogen of Agricultural Systems. Agronomy Monograph 49. USA. 947 p.

Smil, V. (1985). Carbon-nitrogen-sulfur (Modern perspectives in energy): Human Interference in Grand Biospheric Cycles. USA, Plenum press, New York. 412 p.

Truskavec'kij, R. S. (2003). Buferna zdatnist' gruntiv ta yh osnovni funktciy [Soil buffer capacity and their main functions]. Nove slovo, Kharkiv (in Ukrainian).

Tyurin, I. V. (1965). Organicheskoe veshchestvo pochvy i ego rol $\mathrm{v}$ plodorodii [Organic matter of the soil and its role in fertility]. Nauka, Moscow (in Russian).

Vlasyuk, P. A. (1962). Dovidnyk ahronoma po udobrennyu [Handbook of Fertilizer Agronomist]. Derzhsil'hospvydav, Kyiv (in Ukrainian).

Yakist' gruntu. Preparatyvne vydilennya humusovykh rechovyn gruntu [The soil quality. Preparation of soil humus substances]. DSTU 7606:2014. [Chynnyy vid 2015-07-01]. Kyiv: Derzhspozhyvstandart Ukrayiny, 2014. 13 s. (Natsional'nyy standart Ukrayiny) (in Ukrainian).

Yakist' gruntu. Viznachennya vmistu legkogidroliznogo azotu za metodom Kornfilda [The soil quality. Determination of maintenance of easily hydrolysable nitrogen by Kornfild method]. DSTU 7863:2015. [Chinniy vid 2016-07-01]. Kyiv: Derzhspozhivstandart Ukrayiny, 2015. 14 s. (Natsional'nyy standart Ukrayiny) (in Ukrainian).

Yakist' gruntu. Vyznachennya enerhetychnoho potentsialu gruntu kalorymetrychnym metodom [The soil quality. Determination of the energy potential of soil by calorimetric method]. DSTU 7866:2015. [Chynnyy vid 
2016-07-01]. Kyiv: Derzhspozhyvstandart Ukrayiny, 2015. 13 s. (Natsional'nyy standart Ukrayiny) (in Ukrainian).

Yakist' gruntu. Vyznachennya hrupovoho skladu humusu za metodom Tyurina $\mathrm{v}$ modyfikatsiyi Kononovoyi ta Byel'chykovoyi [The soil quality. Determination of humus group composition by Tyurin method in modification of Kononova and Belchikova]. DSTU 7855:2015. [Chynnyy vid 2016-07-01]. Kyiv: Derzhspozhyvstandart Ukrayiny, 2015. 13 s. (Natsional'nyy standart Ukrayiny) (in Ukrainian).

Yakist' gruntu. Vyznachennya hrupovoho ta fraktsiynoho skladu humusu za za metodom Tyurina u modyfikatsiyi Ponomar'ovoyi ta Plotnykovoyi [The soil quality. Determination of the group and fractional composition of humus by the Tyurin method in the modification of Ponomarevoj and Plotnikovoj]. DSTU 7828:2015. [Chynnyy vid 2016-07-01]. Kyiv: Derzhspozhyvstandart
Ukrayiny, 2015. 13 s. (Natsional'nyy standart Ukrayiny) (in Ukrainian).

Yakist' gruntu. Vyznachennya shchil'nosti skladennya na sukhu masu [The soil quality. Determination of drying density on dry weight]. DSTU ISO 11272-2001. [Chynnyy vid 200307-01]. Kyiv: Derzhspozhyvstandart Ukrayiny, 2003. 12 s. (Natsional'nyy standart Ukrayiny) (in Ukrainian).

Yakist' gruntu. Metody vyznachannya orhanichnoyi rechovyny [The soil quality. Methods for determination of organic matter]. DSTU 4289:2004. [Chynnyy vid 2005-07-01]. Kyiv: Derzhspozhyvstandart Ukrayiny, 2005. 14 s. (Natsional'nyy standart Ukrayiny) (in Ukrainian).

Yurko, E.P. (1979). Formyi azotsoderzhaschih soedineniy v pochvah Ukrainyi [Forms of the nitrogenated compounds in soils of Ukraine]. Krugovorot i balans azota $\mathrm{v}$ sisteme pochva - udobrenie - rastenie - voda. Nauka, Moscow, 152-156 (in Russian) 